\section{FLOUR MILLING PROBLEMS}

BY HARRY SNYDER

Chemist, Russell-Miller Milling Company

In responding to the request to present a paper on "Flour Milling Problems," at this meeting of the American Chemical Society, I shall discuss briefly some of the problems with which the flour manufacturer has to deal, what is being done to solve them, the aid Chemistry renders in their solution, and the direction wheat and flour investigations should take in order to be of the most use to all concerned: the producer, the manufacturer and the consumer. By flour I mean the fine bolted product of wheat - as this is what is usually understood by the term when one purchases flour in the market.

The flour milling industry is of large proportions. The L. S. Census numbers the mills by the thousands. Although many of those included are old grist mills, by force of circumstances idle, it is estimated that the total number of flour mills either in active operation or capable of being operated is approximately 7,500 , with a total daily capacity of about $x, 000,000$ barrels. The industry is widely distributed, no one state having over 15 per cent of the total flour-making capacity of the country, and no one manufacturer over 4 per cent.

WHEAT

The United States produces annually from 600,000,000 to I,000,000,000 bushels of wheat, from 50 to 70 per cent being raised in the winter wheat states, the balance-being spring wheat. The wheat yield in the Cnited States fluctuates from 12.3 to 16.6 bu. per acre, the average for the past 17 years being about I 4.2 bu. The yield per acre compared by 10-year periods does not appear to be decreasing. There has been a tendency for a decrease in wheat acreage (if we omit the past two years which have stimulated wheat production). The average consumption of wheat in this country is about 5.3 bu. per capita.

The United States is a wheat-exporting country, but how long she will continue to be so no one can accurately predict. While no large areas of virgin land remain to be brought under wheat culture, it is estimated that nearly one-fifth of the land area of this country now classed as "non-tilled agricultural" is suitable for agriculture.

With the application of improved methods of farming the wheat yield could easily be increased 20 per cent or more. Speaking of the agricultural phase of the wheat-supply question as it deeply concerns the miller, I believe we are reaching a point in our agriculture where wheat must be raised as a regular farm crop under good systems of rotation rather than be produced as a virgin soil crop. If the United States is to maintain her prestige for wheat production, it must be through a continuance, or even an improvement, in the production of the best types of wheat for flour and bread-making purposes. The miller occupies an intermediate position between the producer and the consumer. He buys the wheat, makes the flour, sells it to the distributor or consumer and has to shoulder any responsibility as to lack of quality.

There are a number of flour milling problems which are interesting, but of which only brief mention will be made, as variations in the character of wheat from year to year, due to climatic conditions. Some years the miller has to use wheat which contains I4 to 16 per cent of moisture and this results in heavy losses in milling; then again the wheat is dry and more normal conditions prevail. Weeds have become very prevalent, causing much trouble in cleaning the wheat. Smut and fungus diseases, some of which can be largely prevented by proper treatment of the seed wheat, present difficult milling problems. Rust is a factor that some years must be reckoned with. The tendency of wheats at times to become starchy as in yellow berry, the influence of storage upon the quality of the grain and the effect of different methods of storage are other problems with which the miller must be more or less conversant. Many of these problems are worthy of the best attention of our National and State Departments of Agriculture and Experiment Stations.

The miller, as a manufacturer, has entirely different conditions to contend with than the manufacturer where the raw material is absolutely uniform from year to year and where only the process of manufacture needs to be considered in order to make a uniform product. At times, if he secures his raw material at not prohibitive cost, he must obtain it from different states or localities. This he is privileged to do, as is right, provided he maintains his flour qualities and makes no deceptive claims as to the origin of the wheat used. During the past year the very wet harvest time spoiled more or less of the wheat in some of the southwestern states. As a result an appreciable volume of strong wheat has been shipped from the northwest to the southwest, and consequently flour qualities were maintained. In other years, with reverse conditions, the hard southwestern wheats find their way to northwestern points. This is regulated largely by, transportation charges and local conditions. Many small mills, too, in the eastern and central states, find it advantageous to use some northwestern and southwestern wheat to blend with their local wheat. In other countries the blending of wheats is more extensively practiced than in the Cnited States, particularly where there is but little home-grown wheat and the country is dependent upon the surplus of other countries.

\section{PROCESS OF MANUFACTURE}

Flour milling is distinctly a mechanical industry, the object being to remove from the wheat berry the outer coat or wheat bran and the other offal, and to reduce the wheat to a fine state of division, thereby making a product that is in a better physical condition for bread-making and also in a form that is more completely digested and absorbed by the body.

Since the advent of the bleaching processes, suggestions have been made that flour milling is both a mechanical and a chemical industry, but this is not a correct view, because flour milling is in no way primarily dependent upon bleaching processes no matter what the status of bleaching may prove to be. There are no chemical processes involved in the separation of the bran and the wheat offals and in the reduction of the flour, nor are there chemical reagents of any kind employed; hence the problems which arise are necessarily different from those in a manufacturing plant where chemical reagents are used and where a series of chemical changes occur.

The principal features of the milling process are cleaning the wheat, removing the offal, and then the gradual reduction of the stock into flour. By means of "break rolls" the wheat kernels are partially flattened and crushed, making a mechanical mixture of various sized particles: a little break flour, inter mediate particles (called Flour Middlings), and larger sized crushed or flattened portions of wheat kernels. All of these particles are separated by means of sieves of different sizes ranging from fine silk with 15,000 or more meshes per sq. in. to coarse wire cloth. The middlings are conveyed to the middlings purifying machines and the coarser stock to another break roll. The purified middlings are in turn gradually reduced to flour by means of smooth rolls. There is no sharp line of division between the flours obtained at the break and the middlings rolls. Some of the middlings are no more free from fiber and débris particles than the best of the break flours. Much depends 11pon the system of milling employed and the skill of the miller in making the mechanical separations. The break and reduction rolls and the middlings purifier are among the essential features of the gradual reduction process. If a short break system of milling is etnployed with a minimum of purification, the flour is not so free from dust, fiber, and débris particles. In general, the cleaner and purer the flour, the better its baking qualities. 


\section{APPLICATION OF CHEMICAL TESTS}

The task of distinguishing between flours of various degrees of commercial quality is complicated by three sets of factors: (r) Variations in wheat qualities not susceptible to chemical determinations, (2) lack of uniformity as to milling processes, and (3) lack of sufficiently refined methods to distinguish differences in proportion to commercial values.

One of the methods proposed for determining the mechanical grade of a flour is from the ash content. So far as I am aware I was the first to propose this method, about 25 years ago. I, therefore, feel at liberty to discuss the subject fully. As I have published a number of articles relative to the ash content and the grade of a flour, there is but little to add at this time other than to say that my view now is substantially the same as expressed in my writings. ${ }^{1}$

"Flour made from fully matured wheat has the minimum ash content because high maturity is usually accompanied by low ash. The ash determination, alone, cannot be used to establish the comparative value of two samples of flour containing, respectively, 0.36 and 0.40 per cent ash; the one with the lower per cent ash is not necessarily the better flour. If, however, two samples of flour contain 0.42 and 0.55 per cent ash, respectively, the former is a patent and the latter a straight grade flour. When making comparisons, however, too strict an application of the results is not admissible, particularly when the ash determinations are made in different laboratories and by different analysts, as the results then are not always strictly comparable. When the ash determinations are made under similar conditions the results are of much value in determining the grade of a flour." (Minn. Expt. Sta., Bull. 85, p. I92.)

In my published works I have placed the ash content of patents as ranging from 0.35 to 0.48 per cent, straight grade from 0.48 to 0.55 and clears from 0.60 to I.80 per cent. In my "Human Foods," p. I45, I state:

"Patent grades of flour rarely contain more than 0.55 per cent ash, the better grades less than 0.5 per cent. The more completely the bran and offals are removed during the process of milling, the lower the per cent of ash. The ash content, however, cannot be taken as an absolute guide in all cases as noticeable variations occur in the amount of mineral matter or ash in different wheats. Starchy wheats that have reached full maturity often contain less than hard wheats grown upon rich soils where the growing season has been short, and from such wheat a soft, straight flour may have as low a per cent of ash as a hard first patent flour. When only straight or standard patent flour is manufactured by a mill, all the flour is included which wonld otherwise be designated as first and second patents and first clear."

As these quotations are from my published works of years ago, and prior to my becoming a miller, or identified with the milling industry, any similar statements that I may now make concerning the application of ash tests in determining the grade of flours can not be regarded as biased. As previously stated, ash determinations made in different laboratories and by different analysts are not always comparable.

To what extent do variations in the ash content of a flour occur when the same sample is tested in different laboratories and by different analysts? Such a test was made by the Association of Official Agricultural Chemists and is reported in Bureau of Chemistry Bulletin $\mathbf{1 5 2}$ (Proc. 2gth Annual Convention, Ass'n of Agr. Chemists, p. I07). "Sample $A$ was a straight flour from Fife wheat." The wheat was stored and milled at "the mill at the North Dakota Agricultural Experiment Station."

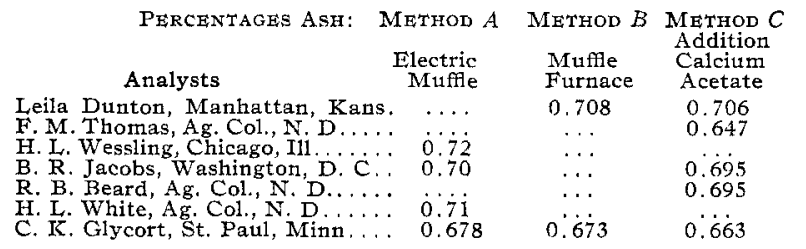

1 Early reports Minnesota Experiment Station; also Bull. 101, O. F. S., U. S. Dept. of Agr.
In commenting upon the tests, Mr. A. S. Mitchell, then in charge of the St. Paul Laboratory of the U. S. Department of Agriculture, aptly states: "Since $A$ and $B$ give practically the same results, there seems to be no necessity for distinguishing between a method in which an ordinary muffle is used and one where an electric muffle is used."

As all of these methods are used by chemists it is fair to draw conclusions as to the variations which may occur when a number of chemists test the same sample of flour. The maximum result is 0.72 , the minimum 0.663 per cent. Hence it would seem fair to say that in well controlled analytical work variations of 0.05 to 0.06 per cent in the ash content of a flour may occur between the results of different analysts. These extremes were found respectively in the Chicago and St. Paul Laboratories of the U.S. Department of Agriculture. With less experienced analysts the differences undoubtedly would be even greater. Since we must allow at least 0.06 per cent tolerance in an ash test of flour for uncontrollable analytical errors, serious difficulties may arise in the practical application of the results.

Suppose a miller sells to a flour dealer $100,000 \mathrm{bbls}$. of flour, not an unusual order. It was agreed that the flour should contain a certain percentage of ash. Suppose the flour declined $\$ 0.50$ or $\$ 1.00$ per bbl., as has been the case the past year, and the purchaser was facing a loss of $\$ 50,000$ or $\$$ roo,o0o. Now if the flour was received and a sample was tested by another chemist and found to have 0.04 or 0.06 per cent more ash than was agreed, the purchaser could claim that he had received a poorer grade of flour than the contract specified. If there really was an actual difference of 0.05 per cent ash, the flour shipped would be worth from 30 to 40 cents a barrel less than the contract grade. On the basis of a difference of 0.05 per cent ash a claim for $\$ 30,000$ to $\$ 40,000$ could be made for damages by the purchaser and there would be an excuse for litigation, when, in fact, there is no basis for any dispute because the 0.05 per cent difference in ash is within the limits of error when flour is tested in separate laboratories by different chemists.

Reverse the conditions-suppose the flour advanced in price. If the miller wished to take advantage of the facts, knowing that two chemists would differ by 0.06 per cent in ash, and knowing that such a factor of tolerance must be allowed, there would be nothing to prevent the order being filled with an inferior flour that would pass the ash test and would not be the quality that the purchaser supposed he was getting.

\section{FLOUR GRADES}

The sample tested by the Official Chemists is a straight grade flour milled at the North Dakota Agricultural Experiment Station, and contains 0.66 to 0.72 per cent ash. It is a type of flour made by what might be termed a mill of very limited or of minimum capacity. How would such a sample compare in ash content with a straight flour made by another mill? That would depend upon the character of the wheat used and the nature of the machinery employed. Dr. Ladd, as chairman of the Flour Standards Committee, Department of Agriculture, proposes "straight flour from hard spring wheat 'contains' not more than 0.52 per cent of ash." If such a standard were adopted Dr. Ladd's flour mill, along with a large number of others, would have to stop making flour, as such a mill's product would be illegal, being a straight flour. with 0.66 to 0.72 per cent of ash, determined by two separate U. S. Department of Agriculture Laboratories and with 0.14 to 0.20 per cent excess of ash over and above the limit of 0.52 per cent. On such a basis the flour would be adulterated or misbranded, probably the latter.

Various attempts have been made to define flour grades. What is patent flour? Who can tell? As well try to answer the question: "How old is Ann?" In discussing flour topics in a recent hearing before the Ways and Means Committee of the House of Representatives on the proposed Mixed Flour Law and the 
amendments to the Pure Food Law, Dr. Wiley aptly answered the question from a chemical point of view (page $374, \mathrm{H} . \mathrm{R}$. 9409).

Mr. RaINEY: "In what way are the different grades of flour designated?"

DR. WILEX: "I am not a miller and I do not know. I know the common names that are applied."

The difficulty is that mills do not have wheat of uniform character from year to year. The wheats differ widely in different parts of the country, and furthermore the equipment in mills is necessarily so varied, in order to mill the different kinds of wheats, that the products designated as patents, straights, or clears are not admissible to classification on a hard and fast basis of ash content, or on the basis of any other constituent or quality.

If these chemical tests are not as yet sufficiently accurate to determine the grade and quality of a flour, are baking or other tests any more accurate and reliable? This question can best be answered by reference to the Association Report previously quoted. The straight flour testing 0.66 to 0.72 per cent ash, as noted, was subjected to baking tests in different State and Government Laboratories. The results showed a range in volume from I 990 to $2520 \mathrm{cc}$, a difference of $530 \mathrm{cc}$. The largest loaf volume was 2.5 per cent more than the smallest loaf. The color values ranged from 90 to $10 x$. The absorption of water for the $340 \mathrm{~g}$. of flour used in baking ranged from 50.2 to 57.3 . It would seem then that allowances of 7 per cent in absorption, 25 per cent in volume and so points in color and texture must be allowed for differences in the work of individuals, testing flour by baking tests. As to the comparisons of gluten tests, but few figures are available, but they show a range from 33.7 to 37.57 for moist gluten and $\mathrm{I} 3 . \mathrm{I}$ to $\mathrm{I} 3.82$ for dry gluten. The total nitrogen content ranged from 2.34 to 2.505 , a difference of 0.165 per cent or about 1.0 of protein. In another report (Aug. I5, I915, Journal of the A ssociation of Official Agricultural Chemists), the dry gluten of two analysts working on the same samples ranged from I0.8 I to 14.63 per cent on one sample, to 10.95 and 13.32 per cent on another sample.

In interpreting the comparative restults of either chemical or bread-making tests of two persons working on the same sample of flour and with the same methods, but in different laboratories, a range of ro to 25 per cent must be allowed for uncontrollable errors, depending upon the feature under comparison. These differences between the results of investigators are well established by the work of the Association of Official Agricultural Chemists. It is better for chemists frankly to admit these limits of error than to attempt to condone them.

I do not wish to leave the impression that chemical and baking tests of flour are of but little value. Their greatest value comes when the "personal error" is reduced to the minimum by the skilled flour technologist who is making the same tests day" after day in the same way, under absolutely uniform conditions and when his results are compared one with another. When millers and bakers get such widely divergent results on the same sample of flour tested by different chemists in different laboratories, they are confused and there naturally arises more or less a feeling of lack of confidence for the whole system of flour testing. I heard one mill manager express himself thus: "If you have a flour tested, be sure and have it tested by a number of chemists so as to have a variety of results to pick from."

A mill owner, Mr. Krafts, of St. Louis, at the hearing before the Flour Standards Committee last June, said in part (p. I68):

"But I don't remember ever having any flour analyzed. Only once I heard of it. Once my partner said to me that somebody said his 95 per cent flout was better than ours, and that he had this thing and that thing in it. I said, 'Maybe it has: What are those things?' I knew we did not put anything like 'em in ours, that's all I knew, and he said, 'Suppose we get some of our samples analyzed, and see.' I said, 'Go ahead, I don't mind,' and so he sent some to some fellow-somebody told him about - and it came back, and he came in and showed me the returns from the doctor. And he said: 'What's this mean-do you know?' and I said: 'Chris, look at that, will you! Look what you have got in the flour.' I knew we hadn't put anything like that in there and that's all I knew. I said: 'What are all these things anyhow?' They didn't convey to my mind anything at all. I rolled it up and threw it in the waste basket, and that's how I know we had it analyzed once."

Another method occasionally employed by practical millers to determine the value of chemical or baking tests is to send separate portions of the same sample of flour, under different names, to the same laboratory for tests. At the hearing to repeal the Mixed Flour Law such an incident is given by Mr. Shoening, a miller of Illinois:

"Now, no man has more respect for a chemist than I have. I have a chemist in my family now. My son is a graduate of the University. He took a special course in chemistry and has a diploma. When he came back I put him to work. I bought him a pair of overalls and made a practical miller out of him. He wanted to run the mill. This is his hobby. Then he began to analyze the flour as he made it. I knew that the flour was uniform, but he got a different result every time he made an analytical test." Then Mr. Shoening tells how he took a sample of flour, divided it into three parts, sent the samples from different express offices to the same laboratory. "Well, sir, when those reports came back - and I have the documentary evidence now in my desk at Columbia, although I have never said anything about it - they were such that if those laboratory tests would govern the price of flour, I would have to sell the same flour, made out of the same wheat -90 cents a barrel less for one sample than I would have to take for the other."

These quotations are not given with any view of discouraging flour testing by chemical or baking methods, but rather to show how many millers actually regard such tests. The fact is, millers in general do not consider flour-testing, as it is ordinarily practiced, of any great value. I think much of this view is due to the chemist not perfecting his methods of investigation, not thoroughly studying the questions involved and attempting to draw definite conclusions on insufficient data. In the case of the ash test, too much is left to the individual judgment of the chemist as to just how far the refining process should be carried so as to secure an ash of definite characteristics. The old distinction between crude ash and pure ash seems to have been discarded. In discussing the ash content of cereals and flours, the Chemical Division of the U. S. Dept. of Agriculture, years ago, ${ }^{1}$ stated some general principles which are particularly applicable to the question. At that time the Official Method was

"The charring of the material at a low temperature, the extraction of the char with hot, distilled water to remove the soluble ash therein and the final combustion of the carbonaceous residue at as low a temperature as possible until an ash fairly free of carbon is secured. While this method can be applied with a fair degree of success to small quantities of cereal flours, and for the purpose of determining simply the percentage of ash therein, the attempt to apply it to considerable quantities for the purpose of securing an amount of ash for the complete analysis is attended with difficulties."

These difficulties are enumerated under four headings, showing whereby excessive temperatures may bring about losses and unbalanced combinations of the ash constituents, and incomplete oxidation on the other hand may leave a considerable amount of carbon. "At best the ashes are of a light gray color and in some cases, owing to the excess of carbon, inclined to be black. The application of sufficiently high temperature to secure complete oxidation produces serious changes in the composition of the ash, rendering complete oxidation difficult."

A crude ash determination cannot be left to the novice. The ash should be granular, and as free from carbon as possible. If fused, a glassy coat of phosphates may be formed causing a dark ash due to occlusion of carbon. Constant weight is not necessarily a criterion of an accurate ash test. Many flour ashes apparently pure are found upon examination with a lowpower microscope to contain innumerable unburned carbon

1 Bull. 13, Part 9, p.1210. 
particles, appearing like unburned coal in coal ashes. Particularly is the ash rich in carbon if too much flour has been burned, say over $2 \mathrm{~g}$., in a dish that is not sufficiently exposed to the air, and where the ash forms an appreciable layer. The best ash results are obtained by long combustion at a low temperature to insure reasonable oxidation of carbon. Such an ash can at the close of the operation be fused, if desired, without loss of weight, provided the temperature is not raised much above $675^{\circ} \mathrm{C}$. An ordinary set of analytical weights of the first class when checked against special standardized weights of the Bureau of Standards may show variations sufficient to cause a difference of nearly 0.02 per cent in an ash test. When we consider all of the possible sources of error in an ash test, it is not surprising that two analysts may show a difference of 0.06 of a per cent when testing the same sample of flour. Errors in drawing samples also occur: these I have discussed in a previous paper and will not consider at this time. ${ }^{1}$

\section{NEW ACIDITY TESTS}

In considering acidity, difficulties arise which are very confusing. The per cent of acid obtained from a sample of flour varies directly with the time of extraction and the temperature employed; hence it is essential that these two factors be uniformly maintained to secure concordant results. The acidity is a measure of a number of things-soluble proteins, certain soluble ash constituents and any free lactic and similar acids that may be present. In the Official Tests as previously mentioned, a variation of o.ro per cent may occur between the results of different investigators working on the same sample (see page 108 for results: $0.29,0.275,0.258,0.198$ and 246 per cent acid obtained by different official workers).

Last year or the year previous the Association of Official Agricultural Chemists adopted as a provisional method a temperature of $40^{\circ} \mathrm{C}$. and a time limit of one hour(?). This method, until further tests are made, should be considered no more than provisional, as it appears to have been tried by only two coöperating chemists although with quite satisfactory results. This method gives somewhat higher figures than obtained formerly where $\mathrm{I} 7^{\circ} \mathrm{C}$. was the temperature employed for extraction. A flour with 0.09 per cent acidity by former tests may show o.I I per cent or so by the present provisional method with a higher temperature for extraction, and hence this year where millers and bakers have had acidity tests made and higher results reported, some have been unnecessarily alarmed, fearing that the excess of acid indicated unsoundness of the flour, when in fact the higher acidity is not due to unsoundness but to changes in methods of analysis. This is confusing to the layman and difficult to explain to him.

\section{FLOUR BLEACHING}

I am not discussing the color of flour, or flour bleaching in this paper, because this matter is still in litigation and its discussion now would be inopportune. There are certain general facts, however, which appear to be established by the U. S. Supreme Court decision in directing a retrial of the case.

"If it cannot by any possibility, when the facts are reasonably considered, injure the health of any consumer, such flour, though having a small addition of poisonous or deleterious ingredients may not be condemned under the act," and "It is not required that the article of food containing added poisonous or other added deleterious ingredients must affect the public health, and it is not incumbent upon the Government in order to make out a case to establish this fact." * * "the added poisonous or deleterious substance must be such as may render such article injurious to health. If the testimony introduced on the part of the respondent was believed by the jury they must necessarily have found that the added ingredient, nitrites of a poisonous character, did not have the effect to make the consumption of the flour by any possibility injurious to the health of the consumer.",

Hence it would appear that the question as to possibility of

1 sth Intern. Congr. Appl. Chem., 18, p. 323.

2 U. S. Supreme Court Decision No. 548, October Term, 1913. injury to the health of the consumer by the use of bleached flour has been disposed of by the Supreme Court decision. This would leave, however, other phases of the question unsettled. It would seem then that bleaching of flour is not to be prohibitive on the basis of any possible injury to health, but if anything is to be done it will be of a regulatory nature. In considering flour bleaching, each method of bleaching, nitrogen peroxide, chlorine, etc., should be considered upon its own merits or demerits as the case may be. The full legal status of flour bleaching should be settled for the general good of the flour trace, and a uniform practice be followed in all parts of the United States.

As a rule, flour made by mechanical processes is not subject to adulteration. The Mixed Flour Law passed by Congress in I 898 , put a stop by regulatory measures to indiscriminate mixing of corn and wheat flours and introducing into flour corn-starch and other materials, which practice at that time was quite threatening to the flour industry. During the past year it has been proposed to repeal this law and amend the present National Pure Food Law, so as to permit the blending of corn-starch and wheat flour without the present regulatory measures-the mixture to be sold under the name of flour. It is a measure which the flour industry opposes practically as a unit.

Unless the miller makes some misstatement in labeling his packages of flour, he has but little to do with food laws, as the fine bolted material made from wheat is flour and there is no possibility for adulteration to occur. In the case of the feeds and wheat offals, a statement of protein content, crude fat and crude fiber is generally given on the package, also a statement as to any screenings present, as most states have laws calling for this data. Usually the labeling of his feeds gives the miller but little trouble, as he generally aims to make the guarantee low enough to cover ordinary fluctuations. However, errors in sampling and analysis arise and sometimes the same goods made from identical wheat on the same day will be tested and reported on favorably by one state inspection and reproved by another as deficient in some constituents, and the miller is warned. This brings up the question as to how much tolerance should be allowed for uncontrollable errors in analysis of a sample of feed. If, say a dozen or more state chemists were all working upon the same sample, to what extent would their results vary? Such tests have been made by the Association of Official Agricultural Chemists.

An interesting report on coöperative total nitrogen tests upon which protein content is calculated is recorded in Jour. Assn. Official Agricultural Chemists (Nov. 15, 1915), p. 380 . Sixteen Official Chemists took part in the work, all testing the same sample for total nitrogen. The Associate Referee who conducted this comparative work remarked: "The figures for total nitrogen are, with the exception of one result, quite satisfactory." Omitting this high result the difference between the lowest and highest nitrogen tests $(2.46-2.76)$ is 0.3 per cent nitrogen, which calculated into protein is equivalent to 1.87 per cent. On the basis of the lowest test 15.37 per cent protein was found, and on the highest 17.25 per cent.

Some state chemists frankly admit that at least r.o per cent or more can be-allowed in a protein test for uncontrollable errors. Other state chemists will not admit any tolerance and stand ready to consider mill feeds below the guarantee if they fall short of 0.50 per cent. There should be a uniform practice followed in all states, and a fair tolerance allowed as chemical analyses of feeds have by no means reached a position where the results of one chemist can be absolutely duplicated by another.

FUNCTION OF THE CHEMIST IN A FLOUR MILL

A small or medium-sized mill cannot afford to employ a chemist regularly. A flour technologist, a person familiar with the manufacture of flour from the mechanical or milling point of 
view, will be of the most service in such mills. Such a person must have a practical knowledge of bread-making and of the general working qualities of flour. In a large flour mill organization there is a place for the chemist provided he is properly equipped for the position. He 8 ust have a fair knowledge of flour milling from the mechanical side, and also a thorough knowledge of technical bread-making, along with his chemical training. The broader his chemical training the better equipped he is for his work. There are many chemical engineering problems' in a mill to investigate, as cost of fuel, reduction of boiler scale, lubricants, strength of cloth used for flour containers, etc. If the chemist can help reduce the cost of a barrel of flour even a fraction of a cent, he is assisting materially in the general economy of production.

\section{FLOUR RESEARCH}

The main part of the chemist's work should be research. Many of the possible problems are of such a character as to escape entirely the notice of chemists not intimately connected with a flour milling plant. Such a problem is wheat storage in its relation to flour qualities. The wheat kernel undergoes a cycle of interesting changes from the time of harvest until it reaches what might be termed its old age. These are largely cell respiration changes. The activity of the germ and the products which it forms are interesting questions. Our ordinary methods of analyses are not sufficiently refined to investigate many of the problems. Some of the methods employed in measuring changes in physical chemistry are promising. A slight increase in soluble constituents, as changes preceding germination, are reflected in the conductivity. The chemist and flour technologist can closely coopperate in the study of many questions, but the chemist must not get the mistaken idea that his analyses will point the way to the solution of all of a mill's problems. He must coöperate with all departments. If, along with the necessary equipment for his position, he has a fair business knowledge, he may occasionally make suggestions that will be of some value. A little of the time of the chemist will necessarily be given to routine work, but this he can well afford to reduce to the minimum as the flour technologist can generally give more and better information than can the chemist from the chemical analysis alone. A good flour technologist often makes a poor chemist, and a good chemist often proves a poor technologist. Chemical and technical knowledge are sometimes possessed by the same individual to a fair degree.

Many of the problems in connection with wheat and flour are of a biochemical nature. I use this term advisedly as it is becoming such a popular one that there is a tendency to use it indiscriminately, and I fear some of the courses of instruction in biochemistry that have sprung into existence "over night," as it were, will need to be greatly strengthened in order to prove satisfactory.

It is as difficult in wheat and flour work to measure life processes by chemical analysis as it is elsewhere in the animal and vegetable world. Two flours may have practically the same percentage composition in protein, starch, and other constituents and yet have widely different values for bread-making purposes. It is not possible to take a flour of high protein content, dilute it with starch from any cereal so that it will show the same amount of protein or crude gluten as some other flour and have the two alike in their bread-making qualities. There is an individuality to wheats and flours which is not as yet susceptible to exact measurements by chemical methods. It is not only a question of the per cent of constituents in a flour, but also of their interrelationship and the way in which the flour responds in bread-making. Some of the factors which impart quality to flour for bread-making purposes are well known, others are not; some even impart a negative value. It is the sum or total of all of the factors, positive and negative, which must be considered in reaching a conclusion, rather than any one factor.
Since the modern reduction process of flour milling is of such recent development, much of the literature and the traditions of flour making apply to the old mill-stone days when a less refined product was made. There are some who still argue with vehemence that the old grist mill and millstone flour is superior to the modern product. A few facts will, I believe, help to place before you the difference between the two flours so that comparisons can be made. In the old gristmill days little or no attention was paid to the cleaning of the wheat, and in the milling process somé of the bran and fiber were reduced with the flour, and the flour middlings were not completely removed from the bran and offal. The flour was dark in color, mainly on account of its dirt content, and if used at once made very good bread, but soon developed a so-called "nutty flavor." The flour had poor keeping qualities because it was poorly milled and was not made from thoroughly cleaned wheat. The nutty flavor was due to the first stages of butyric acid fermentation, the ferments being associated with the dirt and impurities in the flour. Modern, well-milled flour has good keeping qualities; in fact, it gradually improves with moderate age. In modern flour there is a larger percentage of the total wheat kernel present, although somewhat less of the dirt, bran and fiber. This is due to improvements in the milling system. Modern flour is much cleaner and contains less impurities than the old gristmill product and from a sanitary point of view is a better food product.

The flour chemist must be familiar with nutrition investigations as problems relating to the nutritive value of flour are continually arising. The general public is not well informed upon the nutritive value of foods and frequently is imposed upon by the statements of the uninformed or those who wish to be pecuniarily benefited by the promulgation of such ideas as that ordinary white flour and the bread made from it are deficient in nourishment. Graham Lusk ${ }^{1}$ briefly notes this lack of knowledge as to the value of foods: "Even among educated persons one may hear the grossest error of judgment regarding the nutritive value of a hen's egg, and few of those who eat in restatrants realize that the greatest quota of nourishment which is brought to them lies not in the specific dish served, but in the bread and butter which ostensibly is presented as a gift."

The miller is sometimes violently censured for removing the bran from his flour. It is said that he robs the flour, takes out the most valuable and nourishing part and sells a depleted article to the public. It would be made to appear that the miller was doing this for his own profit. What are the facts? The bran and wheat offals sell for $\mathrm{I}^{1 / 4}$ to $\mathrm{I}^{1 / 2}$ cents per $1 \mathrm{~b}$., while his flour sells for $2^{1 / 2}-3$ cents per $1 \mathrm{~b}$. It certainly would be financially to the benefit of the miller to sell bran at flour prices. Where, then, is there any gain to the miller for the so-called robbing of the flour of its most nutritious part? The general public do not want and will not buy four containing bran, and the public cannot be coerced in matters concerning food any more than they can in religion or politics. Then, too, there is sound reason in the public demand for white flour bread in preference to bread with bran. The extensive experiments conducted by the U.S. Department of Agriculture, covering a series of years, have plainly demonstrated that the flours with the larger particles containing the bran are not so completely digested and absorbed by the body as the fine flours containing no bran. The bran lowers the digestibility and the availability of the nutrients in the bread. There are cases where this may be an advantage, but not in the case of normal persons as the average mechanic or laborer. There are also individuals who are benefited by the mechanical action of the bran during digestion, but these cases form no valid basis for reasoning that all persons of normal digestion should eat only bread containing the bran.

England, a short time ago, was violently agitated by the Bread Reform League's advocacy of standard bread, bread made 
from standard flour containing bran. A Commission of Parliament finally had to investigate the subject and wisely reported that what was most important was increasing the protein content of wheats and encouraging the use of flours'with the maximum of gluten or protein.

Another accusation occasionally made against bread is that it is deficient in phosphates and mineral matter. The chief function of flour is to furnish protein and carbohydrates cheaply and in liberal and well proportioned amounts, but it furnishes also liberal amounts of mineral matter. In a study of the question some years ago, Dr. H. W. Wiley ${ }^{1}$ in discussing the mineral matter of flours says: "Enough is left, however, not only to supply the need of the body for mineral constituents, but also for the condimentary purposes mentioned above." Graham Lusk says: "However, those who live on the usual mixed diet rarely suffer salt hunger." The term salt being used in the broad sense to indicate mineral matter. "Salts, therefore, scarcely enter into the food as an economic question." The layman fails to appreciate that phosphates are included in the mineral matter and "salts" along with inorganic or ash constituents as a group.

\section{PROTEINS IN FLOUR}

The more recent investigations of the proteins, particularly of their derivative and component parts, show that not all proteins have the same nutritive value. Some contain a larger number of typical substances necessary for growth and muscular construction and others are deficient even in certain derivative products. To call a substance a protein does not necessarily signify its absolute food value. This brings up the question: What of the proteins of flour? Generally speaking, a flour with I 2 per cent protein has about 5 per cent each of gliadin and glutenin, and about 2 per cent collectively of a number of other proteins, albumins, globulins and proteoses. The gliadin is the glue-like body particularly characteristic of wheat and which serves as the "binder" of the gluten. The glutenin has all the essential components for purposes of nutrition, and ranks equally with any protein as casein, or meat proteins, or ovalbumin for "all sufficient sources of protein supply."2 There is present in flour approximately 6 per cent of these proteins of the $A$ or highest grade, which is twice as much as is found in milk, and besides these there are 6 per cent more of gliadin and similar proteins to serve for general conservation purposes. The proteins of corn, the zeins, are not the equals of the wheat proteins, as the zeins do not contain in their make-up certain component substances necessary for growth. Recent investigations and the views advanced in regard to the nutritive value of the proteins in no way affect the high position which flour and bread occupy in the dietary, because flour contains so much of the growth promoting proteins combined with the conservation proteins.

There are other substances, such as vitamines, which are receiving deserved attention in the study of foods. These protein derivative substances, the products of cell activities of both plant and animal substances, take a very important part in nutrition since in their absence neurotic conditions arise from malnutrition. The vitamine bodies are particularly lacking in such foods as rice and corn which are deficient in protein. Beriberi and pellagra are diseases caused by the use of large amounts of foods which are deficient in protein and vitamines. Pellagra occurs mainly in those localities of the United States where the average consumption of wheat per capita falls below 4.6 bu., and not in the states consuming the average of 5.3 or more. According to statistics pellagra is practically absent where a liberal diet is used in which bread forms an essential part.

In this connection it is interesting to note that vitamines are produced from the activity of the yeast plant, and hence bread

\footnotetext{
I "Food and Food Adulterants," Bull. 13, Part 9, p. 1217.

${ }^{2}$ G. I I11sk, p. 22
}

made with yeast contains not only the vitamine of the flour but also that made by the action of the yeast plant during breadmaking. In fact, Funk of the Lister Institute in the study of beriberi and its cure obtained the vitamine principle from yeast. Whether the temperature in baking is sufficient to destroy completely vitamine products has not been demonstrated, but it would appear that it is not, as the interior of the moist loaf in baking does not reach a particularly high temperature. In the case of polished and unpolished rice in the pellagra question, no study appears to have been made of the vitamine products contributed by the wild yeast. present on the surface of the rice and a constituent of the rice polish.

VITAMINE CONTENT OF OLD AND MODERN FLOURS

Illogical comparisons are sometimes attempted as to the vitamine content of old millstone and modern flour. It is asserted that the old flour contained the vitamines in abundance while the modern flour contains none. What are the facts? In the absence of exact quantitative methods for determining vitamines, indirect means are employed. It is argued that as more of the bran and fiber are removed from the modern flour it must of necessity contain less vitamines. But here is one fallacy of argument; bolting-cloths and sieves were used in making the old flour long before the advent of modern milling. The difference in bran content between the two is altogether too slight to ascribe special vitamine virtues to the one and not the other. Furthermore, in modern milling the flour layers supposedly richest in vitamines are now more completely recovered than in the old gristmill product when much of these flours went with the feeds. Now in the end the two flours, old and new, stand on the same basis as to vitamine content.

Bread enters into the dietary to a greater extent than would appear from a superficial view of the subject and is justly designated "the staff of life." The Eastern, Northern, Central and Western States all consume more flour than the Southern States. The U.S. Department of Agriculture estimates the consumption of wheat per capita as ranging from 4 to $4^{1 / 2}$ bu. in Georgia, Florida, North and South Carolina, Alabama, Mississippi, Kentucky and Tennessee, and from 6 to 7.2 bu. per capita in all of the states west of the Rockies except California, also in Minnesota, the Dakotas, Colorado, Wyoming and Oklahoma. The remaining states consume from $4^{1 / 2}$ to 6 bu. per capita, the general average being 5.3. Assuming the wheat to weigh $60 \mathrm{lbs}$. per bu, and to yield 72 per cent of flour, it would be equivalent to $240 \mathrm{lbs}$. of flour consumed per capita in the United States.

It is interesting to look at the economic aspect of the question. A family of five persons, two adults and three others, either childien or elderly persons, consuming respectively $0.27,0.24$, $0.19,0.12,0.101 \mathrm{lb}$. of protein per day in accord with our dietary standards, would require a total of $0.92 \mathrm{lb}$. of protein. This family of five consuming the average of $240 \mathrm{lbs}$. per capita of flour would use $1200 \mathrm{lbs}$. of flour per year. Assuming this average flour (the total flour from the wheat) to contain ir.50 per cent protein, the $r 200 \mathrm{lbs}$. of flour would, therefore, contain about $138 \mathrm{lbs}$. of protein. The average dietary of the family called for $0.92 \mathrm{lb}$. of protein per day, or $336 \mathrm{lbs}$. per year; that is to say, over 40 per cent of the most expensive and most important nutrient in the daily dietary of the average individual of the United States is supplied in the flour. In the states consuming $6 \mathrm{bu}$. and more per capita of wheat, 45 per cent or more is thus supplied. Calculations made by the writer a few years ago and based upon the amounts of foodstuffs consumed by the average family, according to statistics of the U. S. Bureau of Labor, show that flour costs about one-tenth as much as all other foods combined, although it furnishes over 40 per cent of the total protein and over 50 per cent of the energy of the daily ration.

The per capita consumption of flour in the United States is not as large as in some countries where cheap foods are neces- 
sary. A barrel of the best flour rarely retails for upwards of $\$ 8.50$. During the past twenty years it has been much below this figure. Even if flour should be sold at retail in small lots at 5 cents per pound it would still be the cheapest and best food to form the basis of a dietary.

There are other economic phases of the flour question that deserve brief mention. There are upwards of 66,000 persons engaged in various ways in the milling industry, over 40,000 as daily wage earners, i i,00o clerks and salaried officers and about I5,000 proprietors and firm members. The total pay-roll is over $\$ 35,000,000$ annually. The flour mills represent a capital investment of over $\$ 400,000,000$, pay over $\$ 2,000,000$ in taxes, and manufacture nearly a billion dollars' worth of products in a year, and over 95 per cent of this sum is paid out for raw material and cost of manufacture and sales. This and similar data previously given are taken from U. S. Census Reports, abstracted and compiled in the Millers' Almanac, I9I6, published by the Northwestern Miller, Minneapolis, Minn.

It is very essential that the export four market be kept open, otherwise many flour mills will be idle. If all the flour mills of the country were operated to full capacity for a little over three months (IOO days), they would make enough flour for home consumption. There is no industry in which there is fiercer competition for trade-both domestic and foreign-than in flour milling, and it is safe to say that the average profits per year are materially less than 10 cents per barrel. A number of years ago my attention was called to the singular fact that a company was saved from having a deficit by using a barrel containing two less hoops than formerly. It is right that the chief food of a nation should be made not only as cheaply as possible, but also as good as possible.

What is most needed at the present time is that more attention be paid to the production of good wheats, particularly those of high protein content. Since four enters so largely into the dietary it cannot be made too good. Professor Mendel ${ }^{1}$ aptly. says: "Of all the food stuffs the proteins offer the most serious problem. They represent the indispensable staple for tissue construction; they are produced at the greatest expense." While in the case of some persons too much protein may be consumed, as when meats are used to excess, any trouble would be obviated and a better balanced and cheaper ration secured by the use of more bread and less meat. It is not intended to convey the idea that one "should live on bread alone," any more than that we should live on any single food material, but if a person had to live on any one food, bread would be the best to use. Any attempt to lessen the protein content of flour and increase its starch or carbohydrate content must be regarded as a serious menace to the nutritive value of our chief article of diet. Professor Mendel ${ }^{2}$ notes a tendency for a bread and potato diet to be deficient in protein. In speaking of the industrial workers coming from the country to the city, he says: "They cannot well get along with their former simple diet, because the cheap food materials which one easily obtains, as bread and potatoes, contain too little protein. They undoubtedly need an increase of proteid material." There is certainly no need for any increase in starchy materials to combine with bread.

\section{BREAD-MAKINC}

Another important need is a better understanding of the principles of bread-making, and a wider diffusion of our present knowledge of the subject. There is too much poor bread and this is due to a lack of knowledge. Bread-making is an art founded upon scientific principles. Rule-of-thumb methods for bread-making should give way in our Domestic Science Courses to a study of principles, so that the manipulator will vary the method of procedure and the amount of ingredients to conform to the character of the flour used. It is just as neces-

1 "Changes in the Food Supply and Their Relation to Nutrition," p. 20.

${ }^{2}$ Loc. cil., p. 25. sary to make slight variations in the process of bread-making as it is to make slight changes in butter-making.

Generally the quantity of bread consumed is regulated by its quality. Good bread is eaten with a relish, poor bread with indifference or not at all. If it is desired to economize in the cost of living, the amount of bread used in the dietary must be increased, because there is no food at ordinary market prices that furnishes such a large amount of valuable nutrients in a balanced form and at such a low cost as flour. Hence it is economy to encourage in every way a wider use of bread and flour in the dietary. There are other gains beside economy. Mendel ${ }^{1}$ quotes Rubner as saying: "Long ago the medical profession started an opposition to the exaggerated meat diet, long before the vegetarian popaganda was started. It was maintained that flour-foods, vegetables and fruit should be eaten in place of the over-large quantities of meat."

Flour milling problems and nutrition questions are closely related and demand the best thought and attention that science can give. These questions must be approached in a broad way and in the right spirit. They are not questions for the charlatan, or the zealot food reformer to toy with. They are of such importance that they are destined to be studied until correct scientific conclusions are obtained. Science cannot be fooled permanently. Adulterated science has been attempted, but like other forms of adulteration it is detectable. Chemists must keep up the ethics of their profession. There should be but one scientific standard for all things. Any business or practice which is not right, or which will not stand the closest scrutiny has no claim to continue its existence.

It is to be regretted that occasionally men possessing some scientific knowledge are willing to use it for selfish ends. Such persons cannot be called scientists, because true science will not be polluted. Scientists may, and often do, differ, but when a person will distort facts, disregard the welfare or general good of the public, or by stealth or cunning injure an industry and knowingly commit unethical acts, such a person rightfully forfeits the respect of scientists. Both government experts and those employed by manufacturers should be above such prac tices. They should leave those who wish to follow such lines, in the language of Kipling:-....." "Sweating and stealing a year and a half behind."

Minneapolis, Minnesota

\section{MANUFACTURED FEEDS FOR LIVE STOCK}

$$
\text { By C. S. MINER }
$$

Manufactured feeds for live stock are known in the trade by a variety of names, viz., Horse, Dairy, Stock, Horse and Mule, Hen, Chick, and Scratch Feeds and usually are composed of mixtures of by-products, mixtures of grains, or mixtures of grains with by-products. The industry is one whose growth has been so recent and so rapid that most of us neither appreciate its magnitude nor realize the part which chemists have come to play in its control. The annual output of manufactured feeds has grown steadily until now it is measured in millions of tons and since practically all of it must be produced under chemical supervision this industry is an important one from the standpoint of the chemist.

The question of chemical control, as it happens, is by no means optional with the manufacturer. In the feed industry in its early days there were many abuses of public confidence. The use of improper ingredients, deceptive labeling, and other fraudulent practices indulged in by the unscrupulous resulted in the passing of State Feed Control Laws designed to protect not only the consumer but the honest manufacturer as well. There are now laws of this sort in over forty states-which means in all the states where there is any market for manufactured feeds - and the large majority of them are ably and energetically administered. Although the variations in the details of these

$$
1 \text { Loc. cit., p. } 24 .
$$

